\title{
Bariatric Surgery and Type 1 Diabetes: Unanswered Questions
}

\section{OPEN ACCESS}

Edited by:

Reina Villareal,

Baylor College of Medicine,

United States

Reviewed by:

Geltrude Mingrone,

Catholic University of the Sacred

Heart, Italy

Carel Le Roux,

University College Dublin, Ireland

*Correspondence:

Vaia Lambadiar

vlambad@otenet.gr

Specialty section:

This article was submitted to

Obesity,

a section of the journal

Frontiers in Endocrinology

Received: 10 January 2020

Accepted: 20 August 2020

Published: 18 September 2020

Citation:

Korakas E, Kountouri A, Raptis A, Kokkinos A and Lambadiari V (2020) Bariatric Surgery and Type 1 Diabetes:

Unanswered Questions.

Front. Endocrinol. 11:525909. doi: 10.3389/fendo.2020.525909

\section{Emmanouil Korakas ${ }^{1}$, Aikaterini Kountouri ${ }^{1}$, Athanasios Raptis ${ }^{1}$, Alexander Kokkinos ${ }^{2}$ and Vaia Lambadiari ${ }^{1 *}$}

' Second Department of Internal Medicine, Medical School, Attikon University Hospital, National and Kapodistrian University of Athens, Athens, Greece, ${ }^{2}$ First Department of Propaedeutic Medicine, Medical School, Laiko General Hospital, National and Kapodistrian University of Athens, Athens, Greece

In recent decades there has been an alarming increase in the prevalence of obesity in patients with type 1 diabetes leading to the development of insulin resistance and cardiometabolic complications, with mechanisms poorly clarified. While bariatric surgery has long been considered an effective treatment option for patients with type 2 diabetes, the evidence regarding its benefits on weight loss and the prevention of complications in T1DM patients is scarce, with controversial outcomes. Bariatric surgery has been associated with a significant reduction in daily insulin requirement, along with a considerable reduction in body mass index, results which were sustained in the long term. Furthermore, studies suggest that bariatric surgery in type 1 diabetes results in the improvement of comorbidities related to obesity including hypertension and dyslipidemia. However, regarding glycemic control, the reduction of mean glycosylated hemoglobin was modest or statistically insignificant in most studies. The reasons for these results are yet to be elucidated; possible explanations include preservation of beta cell mass and increased residual function post-surgery, improvement in insulin action, altered GLP-1 function, timing of surgery, and association with residual islet cell mass. A number of concerns regarding safety issues have arisen due to the reporting of peri-operative and post-operative adverse events. The most significant complications are metabolic and include diabetic ketoacidosis, severe hypoglycemia and glucose fluctuations. Further prospective clinical studies are required to provide evidence for the effect of bariatric surgery on T1DM patients. The results may offer a better knowledge for the selection of people living with diabetes who will benefit more from a metabolic surgery.

Keywords: bariatric surgery, type 1 diabetes mellitus, obesity, weight loss, glycosylated hemoglobin, GLP-1, insulin sensitivity

\section{INTRODUCTION}

In recent decades, the prevalence of obesity and metabolic syndrome among patients with type 1 diabetes mellitus (T1DM) has alarmingly increased. In a study by Liu et al., the percentage of obesity among patients with diabetes aged 3-19 years old in the U.S. was $12.6 \%$, with another $22.1 \%$ found to be overweight (1). The prevalence of obesity was even higher in a study by Price et al. (2), reaching up to $17.2 \%$, with $38.3 \%$ of the 501 adults studied found to be overweight. Many other studies have shown similar results regardless of the age of the patients studied (3-6); in general, $\sim 50 \%$ of patients with T1DM are overweight or obese, with $8-40 \%$ meeting the diagnostic criteria for metabolic 
syndrome (7). The reasons for this kind of epidemic have not been clarified; however, it seems that intensive insulin regimens to achieve optimal glycemic targets along with the frequent use of simple sugars by the patients to overcome hypoglycemic episodes are the main factors. Obesity is a major threat for patients with $\mathrm{T} 1 \mathrm{DM}$ as it triggers a vicious cycle where weight gain leads to insulin resistance which, in turn, leads to increased insulin requirements to achieve glycemic control, resulting in further weight gain. Furthermore, obesity accelerates the occurrence of T1DM at a younger age in patients with a genetic predisposition to the disease $(8,9)$, while it is related to an increased rate of micro- and macrovascular complications $(2,10)$.

Bariatric surgery has long been considered an effective treatment for patients with obesity and type 2 diabetes mellitus (T2DM). In 1995, Pories et al. (11) were the first to demonstrate that $82.9 \%$ of patients with T2DM and $98.7 \%$ of patients with impaired glucose tolerance (IGT) achieved euglycemia for a follow-up period of 14 years after bariatric surgery without antidiabetic medication, and similar results were shown in a study by Buchwald et al. (12), where improvement on glycemic control or total remission of diabetes was observed in $86.6 \%$ of the patients studied. As the beneficial metabolic effects on these patients were attributed mainly to weight loss and the concomitant enhancement of insulin sensitivity, the application of bariatric surgery in patients with obesity and T1DM was discouraged, since insulin deficiency rather than insulin resistance was regarded as the main pathophysiologic mechanism of the disease. Nevertheless, the fact that improvements in glycemic control in T2DM patients take place in the course of the first few days after the surgery, before substantial weight loss is achieved, implies that other, weight-loss-independent mechanisms are also responsible for the metabolic amelioration (13). Data on the effects of bariatric surgery in T1DM is scarce, based mainly on case series with relatively few patients and several case reports, and results are conflicting. In this review, our primary end points are to present the existing data about the results of bariatric surgery on T1DM patients concerning weight loss, reduction in insulin requirements, changes in glycosylated hemoglobin (HbAlc) and metabolic comorbidities, along with the main complications and risks, especially diabetic ketoacidosis (DKA) and hypoglycemia. We then discuss the physiological pathways through which bariatric surgery exerts its beneficial effects and special concerns regarding T1DM patients.

\section{BARIATRIC SURGERY OUTCOMES IN TYPE 1 DIABETES MELLITUS}

Bariatric surgery procedures used to be classified as either restrictive or malabsorptive, depending on their mechanism of action; however, this terminology has been abandoned, as it has been shown that each procedure exerts its effects through multiple mechanisms. The main procedures include (a) adjustable gastric banding (AGB) where an adjustable gastric band is placed around the upper part of the stomach to reduce the stomach size, (b) vertical sleeve gastrectomy (VSG), where a tubular stomach is created by partial gastrectomy of the greater curvature side, (c) Roux-en-Y gastric bypass (RYGB), where a small gastric pouch is created from the proximal portion of stomach and is connected to the distal end of the small intestine by gastro-jejunal anastomosis, while entero-enteral anastomosis $100-150 \mathrm{~cm}$ distal to the gastro-jejunostomy site restores bowel continuity between the bilio-pancreatic limb and the alimentary limb, and (d) biliopancreatic diversion (BPD) with or without duodenal switch, where gastrectomy is done to reduce the stomach capacity, the stomach is connected to the distal small intestine and the excluded bilio-pancreatic limb is connected to the alimentary limb distally. The most commonly applied procedures are RYGB and VSG (14). However, all these techniques have been mainly studied in T2DM; studies that refer to T1DM are mostly retrospective, with a limited number of patients with heterogeneous characteristics. The most beneficial results are observed in terms of weight loss and daily insulin requirements, while data about improvements in $\mathrm{HbA1c}$ demonstrate modest and contradictory outcomes. The main results are summarized in Table $\mathbf{1 .}$

\section{Outcomes in Weight Loss}

Bariatric surgery offers a significant reduction in body mass index (BMI) in patients with obesity and T1DM which is sustained in long term. Czupryniak et al. (15) were the first to show a marked improvement in the mean BMI of three women with obesity who underwent RYGB from $42.2 \mathrm{~kg} / \mathrm{m}^{2}$ preoperatively to $33.5 \mathrm{~kg} / \mathrm{m}^{2}$ post-operatively in a follow-up period of $\sim 7$ years. After an $\sim 3$-years follow-up time, mean reductions in BMI were $11.1,8.3$, and $9.4 \mathrm{~kg} / \mathrm{m}^{2}$ in other cohorts (20-22). In a relatively large cohort of 32 subjects with obesity studied for 4.6 years, the mean percentage of total weight loss (\%TWL) at 12 months after surgery was $30.4 \%$, with a slight decrease at 5 years, reaching $28.1 \%$ (23). Cumulatively, a meta-analysis by Chow et al. (34), including 86 patients in total, showed a reduction in BMI of 13.42 $\mathrm{kg} / \mathrm{m}^{2}$ post-operatively. Another meta-analysis by Ashrafian et al. (35), including 142 patients in total, showed a mean BMI decrease of $11.04 \mathrm{~kg} / \mathrm{m}^{2}$, in a mean follow-up time of 31.8 months. In general, similar results have been demonstrated by every study on the field regardless of the type of intervention applied, the number of patients or the follow-up period $(16-19,24-32,36)$.

\section{Outcomes in Insulin Requirements}

The reduction in body weight after surgery is accompanied by a reduction in total daily insulin requirements in patients with obesity and T1DM. Middelbeek et al. (29) evaluated the postsurgical outcomes in 10 women with T1DM at 1 and 5 years after RYGB. Daily insulin requirements were decreased from 53 to 23 units/day at 1 year, with a slight increase in 31.1 units/day at 5 years, presenting a strong correlation with body weight which followed a similar trend. In accordance with weight loss outcomes, insulin requirements were reduced in the reports by Brethauer et al. (20) and Lannoo et al. (21), with a mean change of 0.34 units/kg/day and 56.33 units/day, respectively. In a study by Robert et al. (25), where the procedures applied on 10 patients with T1DM were either biliopancreatic diversion (BPD) or sleeve gastrectomy (SG), the daily insulin dose was 
TABLE 1 | Effects of bariatric surgery on weight loss, daily insulin requirements and glycosylated hemoglobin in patients with obesity and type 1 diabetes mellitus.

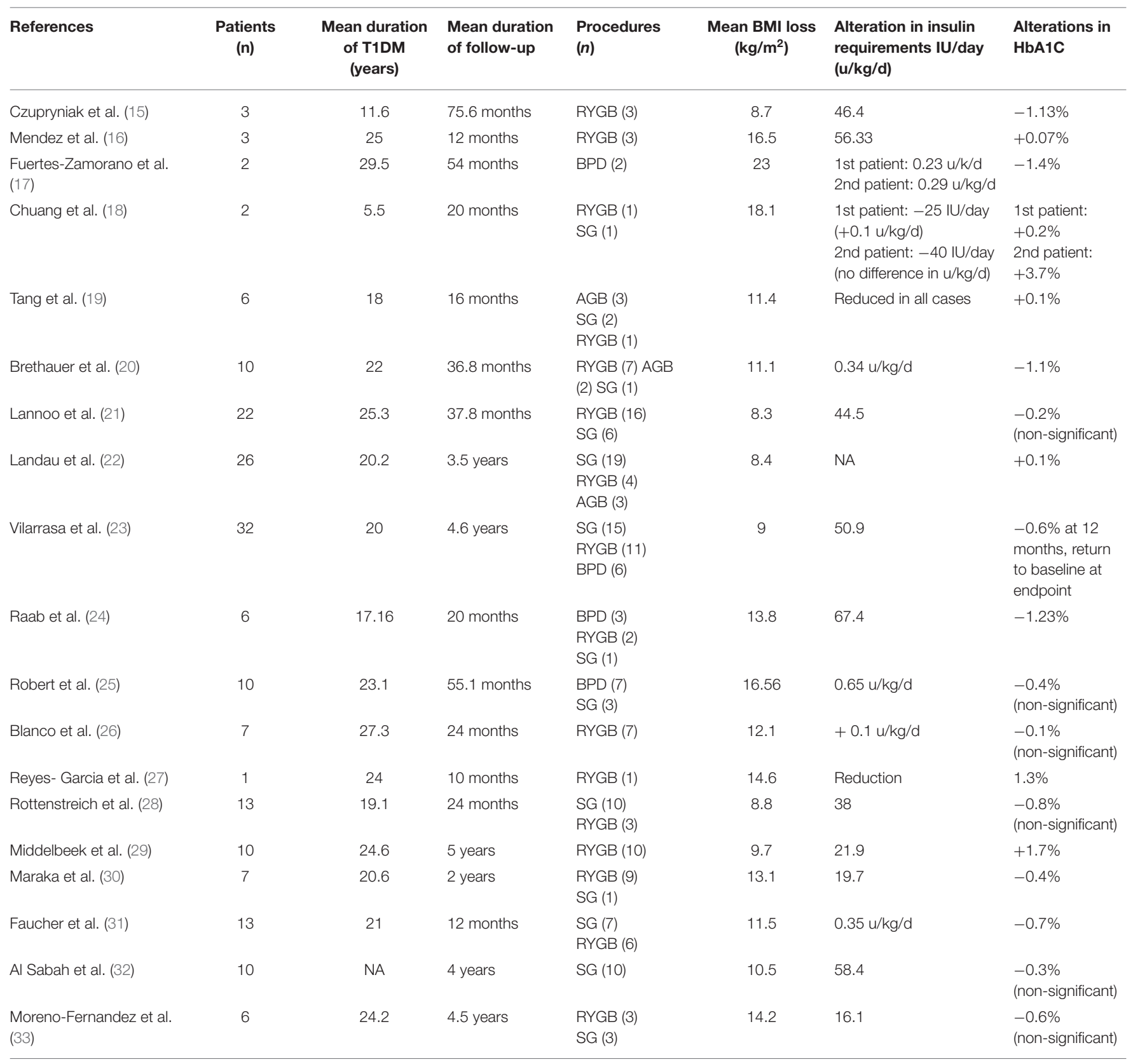

RYGB, R-n-Y gastric bypass; SG, sleeve gastrectomy; BPD, biliopancreatic diversion; AGB, adjustable gastric banding; IU, international units; NA, not applicable; HbA1c, glycosylated hemoglobin A1c; T1DM, type 1 diabetes mellitus.

diminished from 1.09 to 0.44 units $/ \mathrm{kg} /$ day during a mean followup of 55.1 months. The sustained reduction in insulin dose is confirmed in the meta-analyses mentioned above $(34,35)$ where, irrespectively of the follow-up period, the post-operative decrease in insulin requirements was 42 units/day and 0.391 units/kg/day, respectively.

\section{Outcomes in HbA1c}

In contrast to the results concerning weight loss and insulin requirements, the effects of bariatric surgery on $\mathrm{HbAlc}$ seem to be inconsistent among studies. Czupryniak et al. (15) and Raab et al. (24) showed a statistically significant mean decrease in $\mathrm{HbA} 1 \mathrm{c}$ of 1.13 and $1.23 \%$ at 7 and 1 year after surgery, respectively. Similar results were shown by Brethauer et al. (20), where the mean decrease was $1.1 \%$, and by Fuertes-Zamorano et al. (17), who showed a mean decrease of $1 \%$ in two patients who underwent BPD at 5 years post-surgery. However, these favorable outcomes come into contradiction with those in other studies. In the study by Middelbeek et al. (29), the HbA1c was unchanged at 1 year after surgery $(8.1-8.3 \%)$ and, even more interestingly, it 
was increased at 5 years post-operatively to $9.8 \%$. This transient, modest improvement was observed in other studies $(21-23,26$, 28). Overall, as the available meta-analyses indicate, the average mean change in $\mathrm{HbAlc}$ ranges from 0.64 to $0.93 \%(34,35)$; in any case, the optimal target of $\leq 7 \%$ is not reached, meaning that bariatric surgery seems to be barely beneficial in terms of glycemic control. The reasons for this discrepancy are yet to be explained and are discussed below.

\section{Outcomes in Co-morbidities}

The evidence about the impact of bariatric surgery on the common metabolic co-morbidities that accompany T1DM combined with excess weight (so called "double diabetes") is scarce, as many of the already limited studies on the field did not include such risk factors in their endpoints. However, some existing data is encouraging (Table 2). Brethauer et al. (20) showed a reduction in the levels of low-density lipoprotein (LDL) and triglycerides (TG) of 23 and $30.5 \mathrm{mg} / \mathrm{dl}$, respectively, along with an increase in high-density lipoprotein (HDL) of 10.8 $\mathrm{mg} / \mathrm{dl}$. Hypertension resolved in 5 out of 7 hypertensive patients and albuminuria resolved in 1 out of 2 patients who presented microalbuminuria preoperatively. Chuang et al. (18) reported on two adolescents who underwent bariatric surgery. The first one achieved a significant amelioration in his lipid profile (LDL decreased from $180 \mathrm{mg} / \mathrm{dl}$ to $81 \mathrm{mg} / \mathrm{dl}$ and HDL increased from 32 to $45 \mathrm{mg} / \mathrm{dl}$ at 12 months after surgery) and quit statin agents, while he presented with a tremendous improvement in his obstructive sleep apnea. The second patient, suffering from polycystic ovarian syndrome (PCOS) as well, presented a similar improvement in lipids (LDL decreased from 109 to $73 \mathrm{mg} / \mathrm{dl}$ and HDL increased from $41 \mathrm{mg} / \mathrm{dl}$ to $59 \mathrm{mg} / \mathrm{dl}$ at $28 \mathrm{months}$ after surgery) and managed to stop oral contraceptives and restore regular menses. In a long-term cohort, the number of patients with dyslipidemia, obstructive sleep apnea, hypertension and microalbuminuria was decreased by $25,66,42.8$, and $25 \%$, respectively (23). A considerable decrease of $26.9 \mathrm{mg} / \mathrm{dl}$ in triglycerides was observed by Fernandez (33), who studied 6 patients who underwent either RYGB or SG for a mean followup of 4.5 years. In the systematic review by Ashrafian (35), it was estimated that the mean decreases in systolic blood pressure (SBP) and diastolic blood pressure (DBP) were 10.1 and 6.193 $\mathrm{mmHg}$, respectively. Regarding lipid profile, LDL and TGs were reduced by a 9.54 and $11.04 \mathrm{mg} / \mathrm{dl}$, whereas HDL was increased by a mean $13.51 \mathrm{mg} / \mathrm{dl}$. It must be noted, however, that these results were extracted from a very limited number of studies of acceptable quality.

\section{COMPLICATIONS OF BARIATRIC SURGERY}

Bariatric surgery procedures are generally considered safe. The average perioperative mortality is $<0.3 \%$, comparable to this of appendicectomy or cholecystectomy. The 1-year complication rate varies among different procedures, being 4.6, 10.8, 14.9, and $25.7 \%$ for AGB, VSG, RYGB, and BPD, respectively (37). The factors that negatively affect the incidence of adverse events after surgery include male sex, the presence of comorbidities, high pre-operative BMI, old age, and the lack of adequate experience of the surgical team. Among patients with T1DM, no excess in mortality has been reported (38). Apart from the common complications of bariatric surgery, however, an increased prevalence of diabetic ketoacidosis (DKA) and hypoglycemia has been observed (Table 3).

\section{Diabetic Ketoacidosis}

Diabetic ketoacidosis is a life-threatening condition which is not uncommon in patients with T1DM after bariatric surgery. In a study by Aminian et al. (39), the incidence of DKA in the early post-operative period (0-61 days) in T1DM patients was reported to be as high as $25 \%$. Three out of the eight T1DM patients who developed ketoacidosis had a previous episode and all of them had poor glycemic control preoperatively with a mean $\mathrm{HbA1c}$ of $9.3 \%$. In another cohort, $15 \%$ of patients had an episode of DKA within $48 \mathrm{~h}$ after surgery due to insufficient insulin dosage post-operatively (22). Similar results were reported by Maraka et al. (30), where 20\% of T1DM patients who underwent surgery had an episode of ketoacidosis contrary to no incidents in the T2DM group, while in the group of Rottenstreich et al. (28), the incidence of DKA within the first months after surgery was $21.4 \%$. However, DKA poses as a threat even in the long term; 3 out of a total of 32 T1DM patients studied for almost 4.5 years presented with episodes of ketoacidosis within 3 years after surgery (23). Apart from the obviously high prevalence of this complication, another interesting fact is that, in the setting of the reduced carbohydrate intake that follows surgery along with the continued insulin regimen, diabetic ketoacidosis may not necessarily present with hyperglycemia, as in the recently reported case of a 43 yearsold woman who developed euglycemic diabetic ketoacidosis 10 days after she underwent sleeve gastrectomy (40). Rather than altered glucose kinetics, it seems that poor peri-operative glycemic control with discontinuation or inadequate intake of insulin is the main precipitating factor that leads to DKA; others include anesthesia, surgical stress, infection, and fluid and calorie deprivation (39).

\section{Hypoglycemia}

Hypoglycemia is a relatively frequent complication in T1DM patients undergoing bariatric surgery, reaching an incidence of even $70 \%$ (30). The majority of cases pertains to the early post-operative period; in three different cohorts, the rate of hypoglycemic episodes was $18 \%$ (32), 23\% (22), and 29\% (28) within the first few days to months after surgery. Altered glucose kinetics, with the rapid delivery of carbohydrates to the jejunum create an imbalance between the higher and earlier glucose excursions and the action of exogenous insulin, while the improvement in insulin sensitivity that follows weight loss renders the previously needed insulin dosages to become excessive. However, no surgical procedure seems to prevent such episodes, despite the fact that sleeve gastrectomy is considered, in general, to be safer due to a more predictable pattern of carbohydrate absorption. Among 32 patients who underwent either biliopancreatic diversion, sleeve gastrectomy 
TABLE 2 | Effects of bariatric surgery on metabolic comorbidities in patients with obesity and type 1 diabetes mellitus.

\begin{tabular}{|c|c|c|c|c|}
\hline References & $\begin{array}{l}\text { Patients } \\
\text { (n) }\end{array}$ & $\begin{array}{l}\text { Mean duration } \\
\text { of follow-up }\end{array}$ & $\begin{array}{l}\text { Procedures } \\
\text { (n) }\end{array}$ & Effects on co-morbidities \\
\hline Czupryniak et al. (15) & 3 & 75.6 months & RYGB (3) & $\begin{array}{l}\text { Improvements in blood pressure, lipid profile, } \\
\text { microalbuminuria }\end{array}$ \\
\hline Fuertes-Zamorano et al. (17) & 2 & 54 months & $\mathrm{BPD}(2)$ & $\begin{array}{l}\text { 1st patient: resolution of dyslipidemia } \\
\text { 2nd patient: resolution of dyslipidemia and hypertension }\end{array}$ \\
\hline Chuang et al. (18) & 2 & 20 months & $\begin{array}{l}\text { RYGB (1) } \\
\text { SG (1) }\end{array}$ & $\begin{array}{l}\text { 1st patient: no treatment for dyslipidemia, sleep apnea } \\
\text { 2nd patient: restoration of regular menses, stop OCP }\end{array}$ \\
\hline Brethauer et al. (20) & 10 & 36.8 months & $\begin{array}{l}\text { RYGB (7) } \\
\text { AGB (2) } \\
\text { SG (1) }\end{array}$ & $\begin{array}{l}\text { Improvements in LDL }(-23 \pm 19.3 \mathrm{mg} / \mathrm{dl}) \text {, HDL }(10.8 \pm \\
3.4 \mathrm{mg} / \mathrm{dl}) \text {, TG }(-30.5 \pm 17.1 \mathrm{mg} / \mathrm{dl}) \text {. Resolution of HTN } \\
\text { in } 5 / 7 \text { patients, resolution of albuminuria in } 1 / 2 \text { patients. }\end{array}$ \\
\hline Landau et al. (22) & 26 & 3.5 years & $\begin{array}{l}\text { SG (19) } \\
\text { RYGB (4) } \\
\text { AGB (3) }\end{array}$ & Improvements in hypertension, HDL increase \\
\hline Vilarrasa et al. (23) & 32 & 4.6 years & $\begin{array}{l}\text { SG }(15) \\
\text { RYGB (11) } \\
\text { BPD (6) }\end{array}$ & $\begin{array}{l}\text { Remission of HTN, dyslipidemia and OSA in } 42.8,25 \text {, } \\
\text { and } 66 \% \text {, respectively. Regression of microalbuminuria } \\
\text { to normoalbuminuria in } 25 \% \text {. }\end{array}$ \\
\hline Robert et al. (25) & 10 & 55.1 months & $\begin{array}{l}\text { BPD (7) } \\
\text { SG (3) }\end{array}$ & $\begin{array}{l}\text { Remission of hypertension in } 66.7 \% \text {, dyslipidemia in } \\
88.9 \%\end{array}$ \\
\hline Rottenstreich et al. (28) & 13 & 24 months & $\begin{array}{l}\text { SG (10) } \\
\text { RYGB (3) }\end{array}$ & Resolution of hypertension in 4 patients \\
\hline Middelbeek et al. (29) & 10 & 5 years & RYGB (10) & $\begin{array}{l}\mathrm{HDL} \text { increase by } 22 \% \text { at } 5 \text { years. Improvements in } \\
\text { triglycerides and SBP at } 1 \text { year but not at } 5 \text { years }\end{array}$ \\
\hline Maraka et al. (30) & 7 & 2 years & $\begin{array}{l}\text { RYGB (9) } \\
\text { SG (1) }\end{array}$ & Decrease in lipid-lowering medications \\
\hline Moreno-Fernandez et al. (33) & 6 & 4.5 years & $\begin{array}{l}\text { RYGB (3) } \\
\text { SG (3) }\end{array}$ & $\begin{array}{l}\text { Remission of HTN in } 1 / 3 \text { patients. Improvements in TG } \\
(-26.9 \pm 15.1 \mathrm{mg} / \mathrm{dl})\end{array}$ \\
\hline
\end{tabular}

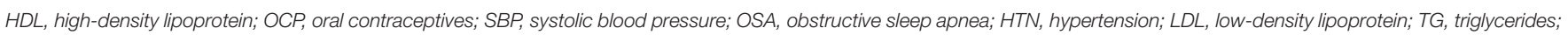
$R Y G B, R-n-Y$ gastric bypass; SG, sleeve gastrectomy; BPD, biliopancreatic diversion; AGB, adjustable gastric banding.

or R-n-Y gastric bypass, three patients (9.3\%) developed severe hypoglycemic episodes within the first year after surgery, one after each procedure applied (23). In a study by Faucher et al. (31), a median of four minor hypoglycemic episodes per week was reported at 6 months after surgery, with more cases being associated with sleeve gastrectomy (median 6 cases) rather than $\mathrm{R}-\mathrm{n}-\mathrm{Y}$ gastric bypass (median 3.5 cases). It is therefore evident that a close monitoring of glucose levels along with careful insulin titration according to the carbohydrate load of each meal is of vital importance in the early post-operative period in order to prevent hypoglycemic episodes regardless of the surgical method used. In this respect, sensor-augmented insulin pump therapy with automated insulin suspension has been related to more stable glycemic control in some patients $(16,26)$, however, adequate data regarding the most efficient type of insulin after surgery is not available.

\section{Other Complications}

As mentioned above, the rate of surgical complication ranges from 4 to $25 \%$, depending on the procedure applied. However, these rates are constantly declining thanks to the improvement in surgical techniques and the existence of more and more experienced bariatric surgery centers. Wound infection and post-operative bleeding, which can derive from the omental or mesenteric vessels or the anastomotic site, are the most common short-term complications after surgery (41). Pulmonary embolism is another common adverse event with a risk of $2 \%$ and, along with anastomotic leak, are the leading causes of death in the early post-operative period. Among the late complications, marginal ulcers, anastomotic stenosis, cholelithiasis, and hernias are the most frequent ones. Among the T1DM population, another common concern is the presence of autonomic neuropathy and gastroparesis, which can lead to complication, such as nausea, vomiting, and acute gastric remnant dilation $(38,42)$.

The most common and serious complications of bariatric surgery are nutritional deficiencies, which occur mainly in malabsorptive rather than in restrictive procedures (43-46). The main nutrients affected are iron, vitamin B12, folic acid, calcium, and fat-soluble vitamins (A, D, E, K). Iron deficiency, depending on the procedure, has a risk of $13-52 \%$ within the first 5 years after surgery, and is attributed to reduced gastric acid production. Vitamin B12 deficiency can occur in up to $70 \%$ of patients after RYGB and is due to the failure of separation of B12 from food and to inadequate secretion of the intrinsic factor $(47,48)$. Folic acid deficiency is less frequent (up to $35 \%$ in patients after RYGB) and its causes include achlorhydria, bypassing of the duodenum, reduced dietary intake and vitamin B12 deficiency $(48,49)$. As calcium is preferentially absorbed in the duodenum and proximal jejunum, the exclusion of these segments leads to malabsorption and hypocalcemia, whose incidence can reach up to $10 \%$ after surgery, while the rate of vitamin D deficiency is 
TABLE 3 | Incidence of diabetic ketoacidosis and hypoglycemia after bariatric surgery in patients with type 1 diabetes mellitus and obesity.

\begin{tabular}{|c|c|c|c|c|c|c|c|c|}
\hline References & $\begin{array}{l}\text { Patients } \\
\text { (n) }\end{array}$ & $\begin{array}{l}\text { Mean duration of } \\
\text { T1DM (years) }\end{array}$ & $\begin{array}{l}\text { Mean } \\
\text { duration of } \\
\text { follow-up }\end{array}$ & $\begin{array}{l}\text { Procedures } \\
(n)\end{array}$ & $\begin{array}{l}\text { DKA before } \\
\text { surgery }\end{array}$ & $\begin{array}{l}\text { DKA after } \\
\text { surgery }\end{array}$ & $\begin{array}{l}\text { Hypoglycemia } \\
\text { before surgery }\end{array}$ & $\begin{array}{l}\text { Hypoglycemia after } \\
\text { surgery }\end{array}$ \\
\hline Chuang et al. (18) & 2 & 5.5 & 20 months & $\begin{array}{l}\text { RYGB (1) } \\
\text { SG (1) }\end{array}$ & $\begin{array}{l}\text { Patient 1: } 1 \\
\text { episode } \\
\text { Patient 2: (-) }\end{array}$ & $\begin{array}{l}\text { Patient 1: }(-) \\
\text { Patient 2: } \\
1 \text { episode }\end{array}$ & $(-)$ & $\begin{array}{l}\text { Patient } 1 \text { : Mild } \\
\text { hypoglycemic episodes } \\
2 \text { to } 5 \text { times per week } \\
\text { Patient } 2 \text { : Mild } \\
\text { hypoglycemic episodes } \\
2 \text { to } 5 \text { times per week }\end{array}$ \\
\hline Aminian et al. (39) & 12 & NA & 90 days & $\begin{array}{l}\text { RYGB (6) } \\
\text { SG (4) } \\
\text { AGB (2) }\end{array}$ & $\begin{array}{l}3 \text { patients } \\
(25 \%)\end{array}$ & $\begin{array}{l}\text { Severe: } 3 \\
\text { Moderate: } 3 \\
\text { Mild: } 6\end{array}$ & NA & NA \\
\hline Maraka et al. (30) & 7 & 20.6 & 2 years & $\begin{array}{l}\text { RYGB (9) } \\
\text { SG (1) }\end{array}$ & NA & 2 patients & NA & 7 patients \\
\hline Vilarrasa et al. (23) & 32 & 20 & 4.6 years & $\begin{array}{l}\text { SG (15) } \\
\text { RYGB (11) } \\
\text { BPD (6) }\end{array}$ & $(-)$ & $\begin{array}{l}2 \text { patients (one } \\
\text { had a recurrent } \\
\text { episode) }\end{array}$ & $(-)$ & $\begin{array}{l}3 \text { patients } \\
(9.3 \%)-\text { severe }\end{array}$ \\
\hline Landau et al. (22) & 26 & 20.2 & 3.5 years & $\begin{array}{l}\text { SG (19) } \\
\text { RYGB (4) } \\
\text { AGB (3) }\end{array}$ & NA & $\begin{array}{l}4 \text { patients } \\
\text { (within } 48 \mathrm{~h} \\
\text { after surgery) }\end{array}$ & NA & $\begin{array}{l}6 \text { patients shortly after } \\
\text { discharge-2 patients } \\
\text { hospitalized }\end{array}$ \\
\hline Faucher et al. (31) & 13 & 21 & 12 months & $\begin{array}{l}\text { SG (7) } \\
\text { RYGB (6) }\end{array}$ & NA & NA & $(-)$ & $\begin{array}{l}\text { Median number of } \\
\text { minor episodes at } 6 \\
\text { months: } \\
\text { RYGB: } 3.5 \\
\text { SG: } 6 \\
2 \text { severe episodes }\end{array}$ \\
\hline Al Sabah et al. (32) & 10 & NA & 4 years & SG (10) & NA & NA & NA & 2 patients $(18.2 \%)$ \\
\hline
\end{tabular}

DKA, diabetic ketoacidosis; NA, not applicable; RYGB, R-n-Y gastric bypass; SG, sleeve gastrectomy; BPD, biliopancreatic diversion; AGB, adjustable gastric banding.

up to $51 \%(50,51)$. The result is the development of secondary hyperparathyroidism, which leads to increased release of calcium from bones and, eventually, loss of bone mass and osteoporosis (52-54). Regardless of the operation performed, all patients who have undergone bariatric surgery should follow a close nutritional monitoring on a regular basis, receiving appropriate supplements when necessary.

Finally, the most recent concern regarding post-surgical complications are psychosocial disorders (55). As the gastrointestinal anatomy after RYGB and SG favors the rapid absorption of alcohol, the rate of alcohol misuse events in these patients is increased and poses as a substitute to their previous food addiction (56-58). Even more alarmingly, the risk of suicide after bariatric surgery seems to rise. In the Utah Mortality Study, a significant increase in the number of suicides, poisonings and accidental deaths after RYGB was observed, and similar were the results in the second Utah Obesity Study $(59,60)$. In 2010, Tindle et al. (61) reported 31 suicides in a total of 16.683 bariatric surgery operations (overall rate of 6.6/10.000), with $70 \%$ of the events occurring within the first 3 years after surgery. In a review by Peterhansel et al. (62) the suicide rate after surgery was estimated to be $4.1 / 10.000$ person-years. A similar trend was shown in 2017 by Laggeros et al. (63), where it was also indicated that episodes of self-harm and depression were more frequent after gastric bypass in patients with a pre-existing psychiatric condition. These data underline the importance of a comprehensive evaluation of the psychiatric status of patients both prior to and after surgery by a multidisciplinary team of experienced healthcare professionals, so that timely identification and management of such conditions is achieved (64).

\section{GLUCOSE HOMEOSTASIS AFTER BARIATRIC SURGERY AND SPECIAL CONCERNS IN T1DM}

As bariatric surgery has only recently been considered as a therapeutic option for T1DM, evidence concerning the possible mechanisms through which it impacts glucose metabolism has been obtained from studies on human and animal models with T2DM. Weight loss, calorie restriction and gastrointestinal hormone modulation are some of the mechanisms which have been described to play an important role in the remission of T2DM after bariatric surgery (65). The effect of these mechanisms in T1DM has not yet been elicited due to the different pathogenesis comparing to T2DM. However, the fact that bariatric surgery results in a significant reduction of insulin requirements and an, at least modest, reduction in $\mathrm{HbAlc}$ in T1DM patients, implies the existence of a shared background between these two types of the disease on which surgery exerts mutually beneficial effects. The discrepancies, nevertheless, in the post-operative glycemic control in T1DM are a serious concern that needs to be elucidated. To discuss these concerns, a brief presentation of the main mechanisms through which surgery acts on glucose metabolism is required. 


\section{Mechanisms of Glycemic Improvement Beta Cell Function and Insulin Secretion}

Bariatric surgery attenuates the dysfunction of beta cells by increasing beta cell sensitivity (66). As it is obvious, in the setting of T1DM, such an action is meaningful only in cases of residual beta cell function. The physiological pathways which mediate this enhancement have been poorly clarified. Caloric restriction, removal of glucose toxicity and gastrointestinal hormone modulation have been proposed; however, it seems that a main mechanism is the enhanced glucagon-like peptide1 (GLP-1) secretion after surgery. The rapid and early delivery of nutrients to the distal small intestine potentiates the secretion of distal gut peptides, mainly glucagon-like peptide-1 (GLP1) and peptide YY (PYY) (67). Post-prandial concentration of GLP-1 rises almost 10 -fold in the first few days after RYGB, and similar increases are observed after SG and BPD, but not after AGB (68-70). The importance of exaggerated postprandial responses of GLP-1 post-operatively has not been studied specifically in T1DM patients after metabolic surgery, however it has been confirmed in studies where the GLP1 receptor was blocked with exendin (9-39) and blunted insulin responses were reported after meals $(71,72)$. In a study by Scrocchi et al. (73), a defective glucose-stimulated insulin secretion was noted in mice which were deprived of the GLP-1 receptor in $\beta$-cells (GLP-1 $\mathrm{R}^{-/}$), while in another murine model of diabetes, the administration of GLP-1R agonist exendin-4 attenuated translational downregulation of insulin and improved beta cell survival (74). Similarly, in a tamoxifen-inducible GLP1R knockout mouse model, augmentation of glucose-stimulated insulin secretion during an oral glucose tolerance test (OGTT) after VSG was blunted in the knockout mice compared to the control group (75); such results were reproduced in another study on humans after RYGB, where administration of exendin 9-39 decreased insulin concentrations $(12.3 \pm 2.2$ vs. $18.1 \pm$ $3.1 \mathrm{nmol} / 6 \mathrm{~h}$ ) and $\beta$-cell response to glucose post-prandially compared to controls (76). In addition, some researchers have attributed post-RYGB hyperinsulinemic hypoglycemia to GLP1 -mediated expansion of $\beta$-cell mass (nesidioblastosis) $(77,78)$, with reversal of the symptoms after blockade of GLP-1 receptor with exendin 9-39 (79). Contrary to these results, a human study comparing RYGB patients with a group undergoing an intensive lifestyle modification therapy showed no differences in glucose tolerance deterioration after the infusion of exendin 9-39 (80). Similar results were demonstrated in animal studies, where the infusion of exendin 9-39 in GLP-1R $\mathrm{R}^{-/-}$and wild type mice which underwent RYGB or VSG resulted in similar glucose tolerance $(81,82)$. Therefore, the role of enhanced GLP1 secretion after bariatric surgery on $\beta$-cell function remains to be clarified. As for the other major incretin, glucose-dependent insulinotropic polypeptide (GIP), evidence is inconsistent, with studies showing contradictory responses after either SG or RYGB (83-85).

\section{Hepatic and Peripheral Insulin Resistance}

The improvement of insulin sensitivity in the early post-operative period is attributed to enhanced hepatic insulin sensitivity (86). This is achieved via a reduction in the liver fat content through increased lipolysis and lipid oxidation (87). It seems that caloric restriction, which occurs immediately after all types of surgical procedures, is the main factor that leads to enhanced hepatic insulin sensitivity. In a study where patients who underwent RYGB were compared with a group who consumed the same very low-calorie diet (VLCD) of 200-300 kcal/day, the improvement in HOMA insulin resistance was $25 \% 4$ days after surgery and similar between the two groups (88). Similar were the results in two other studies, where changes in insulin sensitivity and insulin secretion were either similar or even superior in the first days after RYGB compared to $\operatorname{VLCD}(89,90)$. In another study by Gastaldelli et al. (91), insulin sensitivity was estimated in a group of 20 patients using the more precise method of the hyperinsulinemic-euglycemic clamp, conducted 1 week after a very-low-calorie diet and 1 week after RYGB or LAGB. Both types of surgery led to substantial improvements in hepatic insulin sensitivity and lipolysis compared to diet alone, while RYGB also led to enhanced adipose insulin sensitivity and M/I (peripheral insulin sensitivity divided by the steady-state plasma insulin concentration). Similar results were demonstrated in another study with human subjects, where the hyperinsulinemiceuglycemic clamp 1 week after RYGB showed enhanced hepatic insulin sensitivity and increased insulin clearance (86). On the other hand, in the late post-operative period, peripheral insulin sensitivity is augmented as a result of the substantial weight loss that has been achieved at that point, and a positive correlation has been observed $(68,87)$. Muscelli et al. (92), using the insulin clamp technique in patients who underwent either RYGB or $\mathrm{BPD}$, showed an enhancement in peripheral insulin sensitivity both in the RYGB group $(23.8 \pm 6.0 \mu \mathrm{mol} / \mathrm{min} / \mathrm{kg}$ at 5 months and $33.7 \pm 11.3 \mu \mathrm{mol} / \mathrm{min} / \mathrm{kg}$ at $16 \mathrm{months})$ and in the BPD group $(52.5 \pm 12.4 \mu \mathrm{mol} / \mathrm{min} / \mathrm{kg}$ at 6 months and $68.7 \pm$ $9.5 \mu \mathrm{mol} / \mathrm{min} / \mathrm{kg}$ at $24 \mathrm{months}$ ) after comparable weight loss (53 kg on average). In agreement with these findings, Campos et al. (93) compared patients who underwent RYGB to patients who remained on diet alone at 14 days and 6 months postsurgery, and showed that peripheral glucose uptake, despite being similar at 14 days, was substantially enhanced only in the RYGB group at 6 months. This enhancement is, again, multifactorial. The increase in anorexigenic hormones (GLP-1, PYY, oxyntomodulin) induces early satiety and limited calorie intake. GLP-1 affects the brain indirectly, through vagal nerve fibers in the intestine, whereby it transmits various signals to the nucleus of the solitary tract (NTS), an area in the brain which plays a crucial role in regulating feeding patterns (94). GLP-1R signaling attenuates the release of the orexigenic neuropeptides Neuropeptide Y (NPY) and agouti-related peptide (AgRP), and enhances the release of the anorexigenic neuropeptides proopiomelanocortin (POMC) and cocaine- and amphetamineregulated transcript (CART) $(95,96)$; it increases thermogenesis in brown adipose tissue (BAT) through enhancing sympathetic nervous system activity (97); and inhibits neuronal activity in reward processing areas as functional magnetic resonance imaging (fMRI) studies in obese and T2DM patients have shown (98). PYY levels are parallel to those of GLP-1, and therefore, are also increased after gastric bypass but not after gastric banding $(99,100)$. In addition, as studies in both human 
and animal models have shown, the levels of bile acids are increased after RYGB (but not after SG or AGB), leading to increased secretion of GLP-1 through the TGR5 receptor on L-cells, while they also induce synthesis of fibroblast growth factor 19 (FGF19) on ileal enterocytes which enhances insulin sensitivity through boosting mitochondrial activity (101-104). Finally, metabolic surgery does not contribute only to the decrease of BMI in general, but actually leads to a redistribution of overall body fat mass, while the visceral and intramuscular depot are also reduced, effects which are also mediated, at least in part, by GLP-1, which can induce increased thermogenesis in BAT through various molecular pathways $(65,94,105)$. The improvement in visceral fat and glucose uptake by the skeletal muscle is a result of enhanced insulin sensitivity and the increased GLP-1 levels, which promote glycogen synthesis, glycogen synthase $\alpha(G S \alpha)$ activity and glucose metabolism and, on the other hand, inhibit glycogen phosphorylase $\alpha$ activity, as various studies in both animal and human models have demonstrated (94), while these morphological changes in adipose tissue lead to decreased levels of leptin and other proinflammatory cytokines and increased levels of adiponectin (106, 107). The role of gut microbiota in insulin sensitivity is still to be elucidated $(101,108)$.

\section{Glucose Metabolism}

Glucose absorption is diminished after RYGB and VSG. Regarding RYGB, altered bile acids kinetics lead to the absence of sodium in the alimentary limb, which is necessary for the endoluminal absorption of glucose via the apical sodium glucose cotransporter 1 (SGLT1) (109), while regarding SG, the reduction in glucose absorption is attributed to the reduced leptin- and ghrelin-expressing cells (65). Ghrelin is an orexigenic gut hormone that is produced in gastric fundus and whose postprandial suppression is diminished in individuals with obesity. SG decreases both fasting and post-prandial levels of ghrelin, but such suppression has been shown in RYGB as well, while other studies have shown no change or even an increase (110-112). In addition, after RYGB (but not after SG), the alimentary limb presents mucosal hypertrophy and hyperplasia, which amplifies glucose utilization from the gut (113). Finally, it has been postulated that the exclusion of nutrients from the duodenum eliminates an, unknown, "factor" with anti-incretin properties which leads to hyperglycemia (101). In a study in mice, the group which underwent RYGB presented an increased activity of phosphoenolpyruvate carboxykinase (PEPCK) and glucose6-phosphatase (Glc6Pase) enzymes in the distal jejunum and ileum, thus promoting intestinal gluconeogenesis raising glucose concentration in the portal vein, an effect which is potentiated by GLP-1 and eventually leads to suppressed hepatic glucose production and improved glucose tolerance. These effects were not observed in mice treated with gastric banding (which does not cause redirection of nutrients), as well as in mice with downregulation of the glucose transporter 2 (GLUT2), which is essential for hepato-portal sensing and is stimulated after RYGB $(114,115)$.

\section{Glycemic Control in T1DM: Who Benefits?}

As the above discussed mechanisms reveal, the major pathway through which bariatric surgery beneficially affects glycemic control in T1DM is the enhancement in insulin sensitivity. "Double diabetes" (DD) is the term used to describe the type of the disease which is characterized by the occurrence of factors typical of both type 1 and type 2 diabetes; insulin resistance and autoimmunity against beta cells (116). DD can occur when a patient with T2DM develops autoantibodies against beta cells or when an individual with T1DM becomes obese and consequently develops hepatic and peripheral insulin resistance. Nevertheless, glycemic control after bariatric surgery is far from optimal, and the explanation for this is probably multifactorial. Firstly, in some studies, post-operative inhibition of glucagon secretion was not detected despite the increased GLP-1 secretion. In the study by Blanco et al. (26), where seven women with T1DM were compared with seven women with T2DM for 24 months after RYGB, the similarly enlarged post-prandial GLP-1 secretion between the two groups was not accompanied by suppression but rather by an increase in glucagon secretion. Similar were the findings by Dirksen et al. (117) in a patient at 12 months after RYGB, where the 7-fold increase in GLP-1 was accompanied by an only slight decrease in post-prandial glucagon levels. In addition, the absence of residual $\beta$-cell function in the majority of T1DM patients renders any mechanism that improves insulin secretion useless. The three available studies which directly compared the effects of surgery in T1DM and T2DM patients demonstrated impressive decreases in $\mathrm{HbAlc}$ in patients with C-peptide positive T2DM requiring insulin therapy but not in those with C-peptide negative $\operatorname{T1DM}(25,26,30)$. However, as a number of investigators have reported the presence of residual insulin-positive beta cells in patients with T1DM $(118,119)$, timing of surgery becomes crucial, as GLP-1-mediated effects can help preserve beta cell mass and delay progression to total insulin deficiency if the operation is conducted early in the course of the disease.

Another cause of "remission" of diabetes and exacerbations in glycemic control after an initial improvement in HbAlc after surgery is that the type of diabetes is often misdiagnosed, with many patients actually suffering from latent autoimmune diabetes of the adult (LADA). LADA is defined as a type of T1DM which is characterized by slow development and partial autoimmune destruction of beta cell with onset between 30 and 55 years of age (120). LADA accounts for 9-25\% of adults with diabetes in the general population; in a large meta-analysis on bariatric surgery outcomes on T1DM, the rate of patients with LADA was $3.3 \%$. The diagnosis of LADA is based on low fasting and meal-stimulated C-peptide levels and on existence of antibodies against glutamic acid decarboxylase (GAD65), insulin and/or islet cells. The secretory burden on beta cells elicited by insulin resistance leads to their subsequent apoptosis if the burden is prolonged and this is why at the early stages, adequate glycemic control can be achieved with antidiabetic oral medication, whereas in the progression of the disease insulin will be eventually required (121). Robert et al. (25) have reported a case with latent autoimmune diabetes who weaned 
off insulin 2 years after bariatric surgery. In the literature a case has also been reported in which sleeve gastrectomy induced remission of slowly progressive type 1 diabetes in an patient with obesity (122), with the most impressive results observed in a Japanese cohort of 5 patients with a low mean titer of anti-glutamic acid decarboxylase antibody, where mean HbA1c was reduced from 8.4 to $5.7 \% 1$ year after sleeve gastrectomy with or without duodenojejunal bypass (123). This evidence highlights the importance of meticulous screening for LADA preoperatively, especially in patients with poorly controlled diabetes on oral antidiabetic medication or with a history of DKA or autoimmune diseases, as early surgical intervention to preserve residual beta cell mass and function is even more important in these patients, who are the best candidates for metabolic surgery among T1DM patients. The surgery of choice is still unclear, however, even in these patients; while Robert et al. (25) showed that BPD was superior to SG in terms of weight loss, insulin requirements and resolution of dyslipidemia, other studies (124) suggest that RYGB offer the best risk-to-benefit ratio.

\section{CONCLUSION}

The prevalence of obesity and metabolic syndrome in patients with T1DM has increased significantly. The term "Double Diabetes" has been introduced to describe this type of diabetes in which factors typical of both type 1 and type 2 diabetes co-exist. Bariatric surgery has been suggested as an effective treatment for these patients, although data is scarce, based on case series and retrospective studies. Bariatric surgery results in a significant reduction in body mass index, in total daily

\section{REFERENCES}

1. Liu LL, Lawrence JM, Davis C, Liese AD, Pettitt DJ, Pihoker C, et al. Prevalence of overweight and obesity in youth with diabetes in USA: the SEARCH for diabetes in youth study. Pediatr Diabetes. (2010) 11:411. doi: 10.1111/j.1399-5448.2009.00519.x

2. Price SA, Gorelik A, Fourlanos S, Colman PG, Wentworth JM. Obesity is associated with retinopathy and macrovascular disease in type 1 diabetes. Obes Res Clin Pract. (2014) 8:178-82. doi: 10.1016/j.orcp.2013.03.007

3. Vestberg D, Rosengren A, Olsson M, Gudbjörnsdottir S, Svensson AM, Lind M. Relationship between overweight and obesity with hospitalization for heart failure in 20,985 patients with type 1 diabetes: a population-based study from the Swedish National diabetes registry. Diabetes Care. (2013) 36:2857-61. doi: 10.2337/dc12-2007

4. Islam ST, Abraham A, Donaghue KC, Chan AK, Lloyd M, Srinivasan S, et al. Plateau of adiposity in Australian children diagnosed with Type 1 diabetes: a 20-year study. Diabet Med. (2014) 31:686-90. doi: 10.1111/dme.12402

5. Baskaran C, Volkening LK, Diaz M, Laffel LM. A decade of temporal trends in overweight/obesity in youth with type 1 diabetes after the diabetes control and complications trial. Pediatr Diabetes. (2014) 16:26370. doi: $10.1111 /$ pedi. 12166

6. Holt SK, Lopushnyan N, Hotaling J, Sarma AV, Dunn RL, Cleary PA, et al. Prevalence of low testosterone and predisposing risk factors in men with type 1 diabetes mellitus: findings from the DCCT/EDIC. J Clin Endocrinol Metab. (2014) 99:E1655-60. doi: 10.1210/jc.2014-1317

7. Chillarón JJ, Goday A, Flores-Le-Roux JA, Benaiges D, Carrera MJ, Puig J, et al. Estimated glucose disposal rate in assessment of the metabolic insulin requirements and in co-morbidities related to obesity. However, its effect on glycemic control in T1DM is controversial, as sustainable and meaningful reductions in $\mathrm{HbA1c}$ have not been invariably achieved. Apart from the common complications of BS, diabetic ketoacidosis and hypoglycemia are life threatening conditions with increased prevalence in T1DM patients, which require special concern and whose causal mechanisms are still unclear. Improvement in beta cell function, reduction of hepatic and peripheral resistance and modifications in glucose absorption are some of the mechanisms through which BS improves glycemic control in both type 1 and type 2 diabetes suggesting that the two types of diabetes have partially a common pathophysiological pathway; however, the inadequate glycemic control post-surgery has not yet been explained. In conclusion, bariatric surgery is not yet to be recommended routinely to all T1DM patients. For the time being, those patients with LADA considered the most appropriate candidates for surgery when the operation is conducted at the early stages of the disease, as the surgical intervention preserves beta cell mass and delays progression to total insulin deficiency. For all the other T1DM patients, a careful and multidisciplinary approach is necessary, where individualized and realistic goals will be set. Randomized, prospective trials are required to conclusively evaluate the effects of surgery in T1DM both in short and long term and define the most suitable candidates who will benefit the most out of it.

\section{AUTHOR CONTRIBUTIONS}

All authors listed have made a substantial, direct and intellectual contribution to the work, and approved it for publication. syndrome and microvascular complications in patients with type 1 diabetes. J Clin Endocrinol Metab. (2009) 94:3530-4. doi: 10.1210/jc.2009-0960

8. Fourlanos S, Narendran P, Byrnes GB, Colman PG, Harrison LC. Insulin resistance is a risk factor for progression to type 1 diabetes. Diabetologia. (2004) 47:1661-7. doi: 10.1007/s00125-004-1507-3

9. Franck M, Paquot N, Scheen AJ. Influence of body weight on the natural history of and the therapeutic approaches to type 1 diabetes. Rev Med Liege. (2012) 67:461-7.

10. De Block CE, De Leeuw IH, Van Gaal LF. Impact of overweight on chronic microvascular complications in type 1 diabetic patients. Diabetes Care. (2005) 28:1649-55. doi: 10.2337/diacare.28.7.1649

11. Pories WJ, Swanson MS, MacDonald KG, Long S, Morris PG, Brown BM, et al. Who would have thought it? An operation proves to be the most effective therapy for adult-onset diabetes mellitus. Ann Surg. (1995) 222:33950. doi: 10.1097/00000658-199509000-00011

12. Buchwald H, Estok R, Fahrbach K, Banel D, Jensen MD, Pories WJ, et al. Weight and type 2 diabetes after bariatric surgery: systematic review and meta-analysis. Am J Med. (2009) 122:e5. doi: 10.1016/j.amjmed.2008.09.041

13. Batterham RL, Cummings DE. Mechanisms of diabetes improvement following bariatric/metabolic surgery. Diabetes Care. (2016) 39:893901. doi: $10.2337 / \mathrm{dc} 16-0145$

14. Vasas P, Por F. Surgical options for reducing body weight. Orv Hetil. (2014) 155:971-7. doi: 10.1556/OH.2014.29844

15. Czupryniak L, Wiszniewski M, SzymaÅski D, PawÅowski M, Loba J, Strzelczyk J. Long-term results of gastric bypass surgery in morbidly obese type 1 diabetes patients. Obes Surg. (2010) 20:506-8. doi: 10.1007/s11695-010-0074-6 
16. Mendez CE, Tanenberg RJ, Pories W. Outcomes of Roux-en-Y gastric bypass surgery for severely obese patients with type 1 diabetes: a case series report. Diabetes Metab Syndr Obes. (2010) 3:2813. doi: 10.2147/DMSO.S9981

17. Fuertes-Zamorano N, Sanchez-Pernaute A, Torres Garcia AJ, Rubio Herrera MA. Bariatric surgery in type 1 diabetes mellitus; long-term experience in two cases. Nutr Hosp. (2013) 28:1333-6. doi: 10.3305/nh.2013.28.4.6605

18. Chuang J, Zeller MH, Inge T, Crimmins N. Bariatric surgery for severe obesity in two adolescents with type 1 diabetes. Pediatrics. (2013) 132:e10314. doi: 10.1542/peds.2012-3640

19. Tang A, Milner KL, Tonks K, Campbell LV, Greenfield JR. Comment on Brethauer et al. Bariatric surgery improves the metabolic profile of morbidly obese patients with type 1 diabetes. Diabetes Care. (2014) 37:e2489. doi: $10.2337 / \mathrm{dc} 14-0578$

20. Brethauer SA, Aminian A, Rosenthal RJ, Kirwan JP, Kashyap SR, Schauer PR. Bariatric surgery improves the metabolic profile of morbidly obese patients with type 1 diabetes. Diabetes Care. (2014) 37:e51-2. doi: 10.2337/dc13-1736

21. Lannoo M, Dillemans B, Van Nieuwenhove Y, Fieuws S, Mathieu C, Gillard $\mathrm{P}$, et al. Bariatric surgery induces weight loss but does not improve glycemic control in patients with type 1 diabetes. Diabetes Care. (2014) 37:e1734. doi: $10.2337 / \mathrm{dc} 14-0583$

22. Landau Z, Kowen-Sandbank G, Jakubowicz D, Raziel A, Sakran N, Zaslavsky-Paltiel I, et al. Bariatric surgery in patients with type 1 diabetes: special considerations are warranted. Ther Adv Endocrinol Metab. (2019) 10:2042018818822207. doi: 10.1177/2042018818822207

23. Vilarrasa N, Rubio MA, Miñambres I, Flores L, Caixàs A, Ciudin A, et al. Long-term outcomes in patients with morbid obesity and type 1 diabetes undergoing bariatric surgery. Obes Surg. (2017) 27:85663. doi: 10.1007/s11695-016-2390-y

24. Raab H, Weiner RA, Frenken M, Rett K, Weiner S. Obesity and metabolic surgery in type 1 diabetes mellitus. Nutr Hosp. (2013) 28:314. doi: 10.3305/nh.2013.28.sup2.6711

25. Robert M, Belanger P, Hould FS, Marceau S, Tchernof A, Biertho L. Should metabolic surgery be offered in morbidly obese patients with type I diabetes? Surg Obes Relat Dis. (2015) 11:798-805. doi: 10.1016/j.soard.2014.12.016

26. Blanco J, Jiménez A, Casamitjana R, Flores L, Lacy A, Conget I, et al. Relevance of beta-cell function for improved glycemic control after gastric bypass surgery. Surg Obes Relat Dis. (2014) 10:9-13. doi: 10.1016/j.soard.2013.07.020

27. Reyes Garcia R, Romero Munoz M, Galbis Verdu H. Bariatric surgery in type 1 diabetes. Endocrinol Nutr. (2013) 60:467. doi: 10.1016/j.endoen.2013.01.003

28. Rottenstreich A, Keidar A, Yuval JB, Abu-Gazala M, Khalaileh A, Elazary R. Outcome of bariatric surgery in patients with type 1 diabetes mellitus: our experience and review of the literature. Surg Endosc. (2016) 30:542833. doi: 10.1007/s00464-016-4901-2

29. Middelbeek RJ, James-Todd T, Cavallerano JD, Schlossman DK, Patti ME, Brown FM. Gastric bypass surgery in severely obese women with type 1 diabetes: anthropometric and cardiometabolic effects at 1 and 5 years postsurgery. Diabetes Care. (2015) 38:e104-5. doi: 10.2337/dc15-0396

30. Maraka S, Kudva YC, Kellogg TA, Collazo-Clavell ML, Mundi MS. Bariatric surgery and diabetes: implications of type 1 vs. insulin-requiring type 2 . Obesity (Silver Spring). (2015) 23:552-57. doi: 10.1002/oby.20992

31. Faucher P, Poitou C, Carette C, Tezenas du Montcel S, Barsamian C, Touati E, et al. Bariatric surgery in obese patients with type 1 diabetes: effects on weight loss and metabolic control. Obes Surg. (2016) 26:23708. doi: 10.1007/s11695-016-2106-3

32. Al Sabah S, Al Haddad E, Muzaffar TH, Almulla A. Laparoscopic sleeve gastrectomy for the management of type 1 diabetes mellitus. Obes Surg. (2017) 27:3187-93. doi: 10.1007/s11695-017-2777-4

33. Moreno-Fernandez J, Chico A, Working Group of Diabetes and Technology of the Spanish Diabetes Association, Spain. Bariatric surgery results in patients with type 1 diabetes mellitus on continuous subcutaneous insulin infusion therapy. Endocrinol Nutr. (2016) 63:571-2. doi: 10.1016/j.endoen.2016.09.014

34. Chow A, Switzer NJ, Dang J, Shi X, de Gara C, Birch DW, et al. A systematic review and meta-analysis of outcomes for type 1 diabetes after bariatric surgery. J Obes. (2016) 2016:6170719. doi: 10.1155/2016/6170719
35. Ashrafian H, Harling L, Toma T, Athanasiou C, Nikiteas N, Efthimiou E, et al. Type 1 diabetes mellitus and bariatric surgery: a systematic review and metaanalysis. Obes Surg. (2015) 26:1697-704. doi: 10.1007/s11695-015-1999-6

36. Middelbeek RJ, James-Todd T, Patti ME, Brown FM. Shortterm insulin requirements following gastric bypass surgery in severely obese women with type 1 diabetes. Obes Surg. (2014) 24:1442-6. doi: 10.1007/s11695-014-1228-8

37. Demaria EJ, Winegar DA, Pate VW, Hutcher NE, Ponce J, Pories WJ. Early postoperative outcomes of metabolic surgery to treat diabetes from sites participating in the ASMBS bariatric surgery center of excellence program as reported in the Bariatric outcomes longitudinal database. Anna Surg. (2010) 252:559-67. doi: 10.1097/SLA.0b013e3181f2aed0

38. Kirwan, J.P., Aminian A, Kashyap SR, Burguera B, Brethauer SA, Schauer PR. Bariatric surgery in obese patients with type 1 diabetes. Diabetes Care. (2016) 39:941-8. doi: 10.2337/dc15-2732

39. Aminian A, Kashyap SR, Burguera B, Punchai S, Sharma G, Froylich D, et al. The incidence and clinical features of diabetic ketoacidosis after bariatric and metabolic surgery. Diabetes Care. (2016) 39:e50-3. doi: 10.2337/dc15-2647

40. Dowsett, J., Humphreys R, Krones R. Normal blood glucose and high blood ketones in a critically unwell patient with T1DM post-bariatric surgery: a case of euglycemic diabetic ketoacidosis. Obes Surg. (2019) 29:34749. doi: 10.1007/s11695-018-3548-6

41. Raveendran AV, Chacko EC, Pappachan JM. Non-pharmacological treatment options in the management of diabetes mellitus. Eur Endocrinol. (2018) 14:31-9. doi: 10.17925/EE.2018.14.2.31

42. Han SH, White S, Patel K, Dutson E, Gracia C, Mehran A. Acute gastric remnant dilation after laparoscopic Roux-en-Y gastric bypass operation in long-standing type I diabetic patient: case report and literature review. Surg Obes Relat Dis. (2006) 2:664-6. doi: 10.1016/j.soard.2006.08.005

43. Gletsu-Miller N, Wright BN. Mineral malnutrition following bariatric surgery. Adv Nutr. (2013) 4:506-17. doi: 10.3945/an.113.004341

44. Brolin RE, Leung M. Survey of vitamin and mineral supplementation after gastric bypass and biliopancreatic diversion for morbid obesity. Obes Surg. (1999) 9:150-4. doi: 10.1381/096089299765553395

45. Halverson JD. Micronutrient deficiencies after gastric bypass for morbid obesity. Am Surg. (1986) 52:594-8.

46. Decker GA, Swain JM, Crowell MD, Scolapio JS. Gastrointestinal and nutritional complications after bariatric surgery. Am J Gastroenterol. (2007) 102:2571-80. doi: 10.1111/j.1572-0241.2007.01421.x

47. Rhode BM, Arseneau P, Cooper BA, Katz M, Gilfix BM, MacLean LD. Vitamin B-12 deficiency after gastric surgery for obesity. Am J Clin Nutr. (1996) 63:103-9. doi: 10.1093/ajcn/63.1.103

48. Brolin RE, Gorman JH, Petschenik AJ, Bradley LJ, Kenler HA, Cody RP. Are vitamin B12 and folate deficiency clinically important after roux-en-Y gastric bypass? J Gastrointest Surg. (1998) 2:436-42. doi: 10.1016/S1091-255X(98)80034-6

49. Updegraff TA, Neufeld NJ. Protein, iron, and folate status of patients prior to and following surgery for morbid obesity. J Am Diet Assoc. (1981) 78:135-40.

50. Alvarez-Leite JI. Nutrient deficiencies secondary to bariatric surgery. Curr Opin Clin Nutr Metab Care. (2004) 7:56975. doi: 10.1097/00075197-200409000-00010

51. Brolin RE, LaMarca LB, Kenler HA, Cody RP. Malabsorptive gastric bypass in patients with superobesity. J Gastrointest Surg. (2002) 6:195205. doi: 10.1016/S1091-255X(01)00022-1

52. Guney E, Kisakol G, Ozgen G, Yilmaz C, Yilmaz R, Kabalak T. Effect of weight loss on bone metabolism: comparison of vertical banded gastroplasty and medical intervention. Obes Surg. (2003) 13:3838. doi: 10.1381/096089203765887705

53. Goldner WS, O'Dorisio TM, Dillon JS, Mason EE. Severe metabolic bone disease as a long-term complication of obesity surgery. Obes Surg. (2002) 12:685-92. doi: 10.1381/0960892023210 19693

54. Hamoui N, Kim K, Anthone G, Crookes PF. The significance of elevated levels of parathyroid hormone in patients with morbid obesity before and after bariatric surgery. Arch Surg. (2003) 138:891-7. doi: 10.1001/archsurg.138.8.891

55. Arterburn DE, Courcoulas AP. Bariatric surgery for obesity metabolic conditions in adults. BMJ. (2014) 349:g3961. doi: 10.1136/bmj.g3961 
56. King WC, Chen JY, Mitchell JE, Kalarchian MA, Steffen KJ, Engel SG, et al. Prevalence of alcohol use disorders before after bariatric surgery. JAMA. (2012) 307:2516-25. doi: 10.1001/jama.2012.6147

57. Hagedorn JC, Encarnacion B, Brat GA, Morton JM. Does gastric bypass alter alcohol metabolism? Surg Obes Relat Dis. (2007) 3:5438. doi: 10.1016/j.soard.2007.07.003

58. Klockhoff H, Naslund I, Jones AW. Faster absorption of ethanol and higher peak concentration in women after gastric bypass surgery. Br J Clin Pharmacol. (2002) 54:587-91. doi: 10.1046/j.1365-2125.2002.01698.x

59. Adams TD, Gress RE, Smith SC, Halverson RC, Simper SC, Rosamond WD, et al. Long-term mortality after gastric bypass surgery. N Engl J Med. (2007) 357:753-61. doi: 10.1056/NEJMoa066603

60. Adams TD, Davidson LE, Litwin SE, Kolotkin RL, LaMonte MJ, Pendleton $\mathrm{RC}$, et al. Health benefits of gastric bypass surgery after 6 years. JAMA. (2012) 308:1122-31. doi: 10.1001/2012.jama.11164

61. Tindle HA, Omalu B, Courcoulas A, Marcus M, Hammers J, Kuller LH. Risk of suicide after long-term follow-up from bariatric surgery. Am J Med. (2010) 123:1036-42. doi: 10.1016/j.amjmed.2010.06.016

62. Peterhänsel C, Petroff D, Klinitzke G, Kersting A, Wagner B. Risk of completed suicide after bariatric surgery: a systematic review. Obes. Rev. (2013) 14:369-82. doi: 10.1111/obr.12014

63. Lagerros YT, Brandt L, Hedberg J, Sundbom M, Bodén S. Suicide, self-harm, and depression after gastric bypass surgery: a nationwide cohort study. Ann Surg. (2017) 265:235-43. doi: 10.1097/SLA.0000000000001884

64. Lim RBC, Zhang MWB, Ho RCM. Prevalence of all-cause mortality and suicide among bariatric surgery cohorts: a meta-analysis. Int J Environ Res Public Health. (2018) 15:1519. doi: 10.3390/ijerph15071519

65. Pérez-Pevida B, Escalada J, Miras AD, Frühbeck G. Mechanisms underlying type 2 diabetes remission after metabolic surgery. Front Endocrinol (Lausanne). (2019) 10:641. doi: 10.3389/fendo.2019.00641

66. Ferrannini E, Mingrone G. Impact of different bariatric surgical procedures on insulin action and beta-cell function in type 2 diabetes. Diabetes Care. (2009) 32:514-20. doi: 10.2337/dc08-1762

67. le Roux CW, Aylwin SJ, Batterham RL, Borg CM, Coyle F, Prasad V, et al. Gut hormone profiles following bariatric surgery favor an anorectic state, facilitate weight loss, and improve metabolic parameters. Ann Surg. (2006) 243:108-14. doi: 10.1097/01.sla.0000183349.16877.84

68. Jorgensen NB, Jacobsen SH, Dirksen C, Bojsen-Møller KN, Naver L, Hvolris L, et al. Acute and long-term effects of Roux-en-Y gastric bypass on glucose metabolism in subjects with type 2 diabetes and normal glucose tolerance. Am J Physiol Endocrinol Metab. (2012) 303:E12231. doi: 10.1152/ajpendo.00073.2012

69. Romero F, Nicolau J, Flores L, Casamitjana R, Ibarzabal A, Lacy $A$, et al. Comparable early changes in gastrointestinal hormones after sleeve gastrectomy and Roux-en-Y gastric bypass surgery for morbidly obese type 2 diabetic subjects. Surg Endosc. (2012) 26:2231-39. doi: 10.1007/s00464-012-2166-y

70. Korner J, Inabnet W, Febres G, Conwell IM, McMahon DJ, Salas R, et al. Prospective study of gut hormone and metabolic changes after adjustable gastric banding and Roux-en-Y gastric bypass. Int J Obes. (2009) 33:78695. doi: 10.1038/ijo.2009.79

71. Jorgensen NB, Dirksen C, Bojsen-Moller KN, Jacobsen SH, Worm D, Hansen DL, et al. Exaggerated glucagon-like peptide 1 response is important for improved beta-cell function and glucose tolerance after Roux-en-Y gastric bypass in patients with type 2 diabetes. Diabetes. (2013) 62:304452. doi: $10.2337 / \mathrm{db} 13-0022$

72. Jimenez A, Casamitjana R, Flores L, Delgado S, Lacy A, Vidal J. GLP1 and the long-term outcome of type 2 diabetes mellitus after Roux-en$\mathrm{Y}$ gastric bypass surgery in morbidly obese subjects. Ann Surg. (2013) 257:894-99. doi: 10.1097/SLA.0b013e31826b8603

73. Scrocchi LA, Brown TJ, MacLusky N, Brubaker PL, Auerbach AB, Joyner $\mathrm{AL}$, et al. Glucose intolerance but normal satiety in mice with a null mutation in the glucagon-like peptide receptor gene. Nat Med. (1996) 2:1254-58. doi: 10.1038/nm1196-1254

74. Yusta B, Baggio LL, Estall JE, Koehler JA, Holland DP, Li H, et al. GLP-1 receptor activation improves b-cell function and survival following induction of endoplasmic reticulum stress. Cell Metab. (2006) 4:391406. doi: 10.1016/j.cmet.2006.10.001
75. Garibay D, McGavigan AK, Lee SA, Ficorilli JV, Cox AL, Michael MD, et al. Beta-cell glucagon-like peptide- 1 receptor contributes to improved glucose tolerance after vertical sleeve gastrectomy. Endocrinology. (2016) 157:3405-09. doi: 10.1210/en.2016-1302

76. Shah M, Law JH, Micheletto F, Sathananthan M, Dalla Man C, Cobelli $\mathrm{C}$, et al. Contribution of endogenous glucagon-like peptide 1 to glucose metabolism after Rouxen-Y gastric bypass. Diabetes. (2014) 63:48393. doi: $10.2337 / \mathrm{db} 13-0954$

77. Service GJ, Thompson GB, Service FJ, Andrews JC, CollazoClavell ML, Lloyd RV. Hyperinsulinemic hypoglycemia with nesidioblastosis after gastricbypass surgery. $N$ Engl J Med. (2005) 353:249-54. doi: 10.1056/NEJMoa043690

78. Patti ME, McMahon G, Mun EC, Bitton A, Holst JJ, Goldsmith J, et al. Severe hypoglycaemia post-gastric bypass requiring partial pancreatectomy: evidence for inappropriate insulin secretion and pancreatic islet hyperplasia. Diabetologia. (2005) 48:2236-40. doi: 10.1007/s00125-005-1933-x

79. Salehi M, Gastaldelli A, D’Alessio DA. Blockade of glucagon-like peptide 1 receptor corrects postprandial hypoglycemia after gastric bypass. Gastroenterology. (2014) 146:669-80. doi: 10.1053/j.gastro.2013.11.044

80. Vidal J, de Hollanda A, Jimenez A. GLP-1 is not the key mediator of the health benefits of metabolic surgery. Surg Obes Relat Dis. (2016) 12:122529. doi: 10.1016/j.soard.2016.02.029

81. Mokadem M, Zechner JF, Margolskee RF, Drucker DJ, Aguirre V. Effects of Roux-en-Y gastric bypass on energy and glucose homeostasis are preserved in two mouse models of functional glucagon-like peptide-1 deficiency. Mol Metab. (2014) 3:191-201. doi: 10.1016/j.molmet.2013.11.010

82. Wilson-Perez HE, Chambers AP, Ryan KK, Li B, Sandoval DA, Stoffers D, et al. Vertical sleeve gastrectomy is effective in two genetic mouse models of glucagonlike peptide-1 receptor deficiency. Diabetes. (2013) 62:238085. doi: $10.2337 / \mathrm{db} 12-1498$

83. Goldfine AB, Mun EC, Devine E, Bernier R, Baz-Hecht M, Jones DB, et al. Patients with neuroglycopenia after gastric bypass surgery have exaggerated incretin and insulin secretory responses to a mixed meal. J Clin Endocrinol Metab. (2007) 92:4678-85. doi: 10.1210/jc.2007-0918

84. Korner J, Bessler M, Inabnet W, Taveras C, Holst JJ. Exaggerated glucagon-like peptide-1 and blunted glucose-dependent insulinotropic peptide secretion are associated with Roux-en-Y gastric bypass but not adjustable gastric banding. Surg Obes Relat Dis. (2007) 3:597601. doi: 10.1016/j.soard.2007.08.004

85. Lee WJ, Chen CY, Chong K, Lee YC, Chen SC, Lee SD. Changes in postprandial gut hormones after metabolic surgery: a comparison of gastric bypass and sleeve gastrectomy. Surg Obes Relat Dis. (2011) 7:68390. doi: 10.1016/j.soard.2011.07.009

86. Bojsen-Moller KN, Dirksen C, Jorgensen NB, Jacobsen SH, Serup AK, Albers $\mathrm{PH}$, et al. Early enhancements of hepatic and later of peripheral insulin sensitivity combined with increased postprandial insulin secretion contribute to improved glycemic control after Roux-en-Y gastric bypass. Diabetes. (2014) 63:1725-37. doi: 10.2337/db13-1307

87. Camastra S, Gastaldelli A, Mari A, Bonuccelli S, Scartabelli G, Frascerra $\mathrm{S}$, et al. Early and longer term effects of gastric bypass surgery on tissue-specific insulin sensitivity and beta cell function in morbidly obese patients with and without type 2 diabetes. Diabetologia. (2011) 54:2093102. doi: 10.1007/s00125-011-2193-6

88. Isbell JM, Tamboli RA, Hansen EN, Saliba J, Dunn JP, Phillips SE, et al. The importance of caloric restriction in the early improvements in insulin sensitivity after Roux-en-Y gastric bypass surgery. Diabetes Care. (2010) 33:1438-42. doi: 10.2337/dc09-2107

89. Foo J, Krebs J, Hayes MT, Bell D, Macartney-Coxson D, Croft T, et al. Studies in insulin resistance following very low calorie diet and/or gastric bypass surgery. Obes Surg. (2011) 21:1914-20. doi: 10.1007/s11695-011-0527-6

90. Jackness C, Karmally W, Febres G, Conwell IM, Ahmed L, Bessler M, et al. Very low-calorie diet mimics the early beneficial effect of Roux-en-Y gastric bypass on insulin sensitivity and $\beta$-cell function in type 2 diabetic patients. Diabetes. (2013) 62:3027-32. doi: 10.2337/db12-1762

91. Gastaldelli A, Iaconelli A, Gaggini M, Magnone MC, Veneziani A, Rubino F, et al. Short-term effects of laparoscopic adjustable gastric banding vs. Roux-en-Y gastric bypass. Diabetes Care. (2016) 39:192531. doi: $10.2337 / \mathrm{dc} 15-2823$ 
92. Muscelli E, Mingrone G, Camastra S, Manco M, Pereira JA, Pareja JC, et al. Differential effect of weight loss on insulin resistance in surgically treated obese patients. Am J Med. (2005) 118:51-7. doi: 10.1016/j.amjmed.2004.08.017

93. Campos GM, Rabl C, Peeva S, Ciovica R, Rao M, Schwarz JM, et al. Improvement in peripheral glucose uptake after gastric bypass surgery is observed only after substantial weight loss has occurred and correlates with the magnitude of weight lost. J Gastrointest Surg. (2010) 14:1523. doi: 10.1007/s11605-009-1060-y

94. Rowlands J, Heng J, Newsholme P, Carlessi R. Pleiotropic effects of GLP-1 and analogs on cell signaling, metabolism, and function. Front Endocrinol. (2018) 9:672. doi: 10.3389/fendo.2018.00672

95. Cabou C, Burcelin R. GLP-1, the gut-brain, brain-periphery axes. Rev Diabetic Stud. (2011) 8:418-31. doi: 10.1900/RDS.2011.8.418

96. Seo S, Ju S, Chung H, Lee D, Park S. Acute effects of glucagon-like peptide1 on hypothalamic neuropeptide and AMP activated kinase expression in fasted rats. Endocr J. (2008) 55:867-74. doi: 10.1507/endocrj.K08E-091

97. Lockie SH, Heppner KM, Chaudhary N, Chabenne JR, Morgan DA, VeyratDurebex C, et al. Direct control of brown adipose tissue thermogenesis by central nervous system glucagon-like peptide-1 receptor signaling. Diabetes. (2012) 61:2753-62. doi: 10.2337/db11-1556

98. de Silva A, Salem V, Long CJ, Makwana A, Newbould RD, Rabiner A, et al. The gut hormones PYY 3-36 and GLP-1 7-36 amide reduce food intake and modulate brain activity in appetite centers in humans. Cell Metab. (2011) 14:700-6. doi: 10.1016/j.cmet.2011.09.010

99. Morinigo R, Moizé V, Musri M, Lacy AM, Navarro S, Marín JL, et al. Glucagon-like peptide-1, peptide YY, hunger, and satiety after gastric bypass surgery in morbidly obese subjects. J Clin Endocrinol Metab. (2006) 91:173540. doi: 10.1210/jc.2005-0904

100. Korner J, Bessler M, Cirilo LJ, Conwell IM, Daud A, Restuccia NL, et al. Effects of Roux-en-Y gastric bypass surgery on fasting and postprandial concentrations of plasma ghrelin, peptide YY, and insulin. J Clin Endocrinol Metab. (2005) 90:359-65. doi: 10.1210/jc.2004-1076

101. Madsbad S, Dirksen C, Holst JJ. Mechanisms of changes in glucose metabolism and bodyweight after bariatric surgery. Lancet Diabet Endocrinol. (2014) 2:152-64. doi: 10.1016/S2213-8587(13)70218-3

102. Pournaras DJ, le Roux CW. Are bile acids the new gut hormones? Lessons from weight loss surgery models. Endocrinology. (2013) 154:225556. doi: 10.1210/en.2013-1383

103. Patti ME, Houten SM, Bianco AC, Bernier R, Larsen PR, Holst JJ, et al. Serum bile acids are higher in humans with prior gastric bypass: potential contribution to improved glucose and lipid metabolism. Obesity. (2009) 17:1671-7. doi: 10.1038/oby.2009.102

104. Mencarelli A, Renga B, D’Amore C, Santorelli C, Graziosi L, Bruno A, et al. Dissociation of intestinal and hepatic activities of FXR and LXR $\alpha$ supports metabolic effects of terminal ileum interposition in rodents. Diabetes. (2013) 62:3384-93. doi: 10.2337/db13-0299

105. Gomez-Ambrosi J, Andrada P, Valenti V, Rotellar F, Silva C, Catalan V, et al. Dissociation of body mass index, excess weight loss and body fat percentage trajectories after 3 years of gastric bypass: relationship with metabolic outcomes. Int J Obes. (2017) 41:1379-87. doi: 10.1038/ijo.2017.134

106. Frikke-Schmidt H, O’Rourke RW, Lumeng CN, Sandoval DA, Seeley RJ. Does bariatric surgery improve adipose tissue function? Obes Rev. (2016) 17:795-809. doi: 10.1111/obr.12429

107. Faraj M, Havel PJ, Phelis S, Blank D, Sniderman AD, Cianflone K. Plasma acylation-stimulating protein, adiponectin, leptin, and ghrelin before and after weight loss induced by gastric bypass surgery in morbidly obese subjects. J Clin Endocrinol Metab. (2003) 88:1594602. doi: $10.1210 /$ jc.2002-021309

108. Liou AP, Paziuk M, Luevano JM Jr., Machineni S, Turnbaugh PJ, et al. Conserved shifts in the gut microbiota due to gastric bypass reduce host weight and adiposity. Sci Transl Med. (2013) 5:178ra141. doi: 10.1126/scitranslmed.3005687

109. Baud G, Daoudi M, Hubert T, Raverdy V, Pigeyre M, Hervieux $\mathrm{E}$, et al. Bile diversion in Roux-en-Y gastric bypass modulates sodium-dependent glucose intestinal uptake. Cell Metab.

(2016) 23:547-53. doi: 10.1016/j.cmet.2016.01.018

110. Harvey EJ, Arroyo K, Korner J, Inabnet WB. Hormone changes affecting energy homeostasis after metabolic surgery. Mt Sinai J Med. (2010) 77:44665. doi: $10.1002 / \mathrm{msj} .20203$

111. Cummings DE, Weigle DS, Frayo RS, Breen PA, Ma MK, Dellinger EP, et al. Plasma ghrelin levels after diet-induced weight loss or gastric bypass surgery. N Engl J Med. (2002) 346:1623-30. doi: 10.1056/NEJMoa012908

112. Sista F, Abruzzese V, Clementi M, Carandina S, Amicucci G. Effect of resected gastric volume on ghrelin and GLP-1 plasma levels: a prospective study. J Gastrointest Surg. (2016) 20:1931-41. doi: 10.1007/s11605-016-3292-y

113. Saeidi N, Meoli L, Nestoridi E, Gupta NK, Kvas S, Kucharczyk $\mathrm{J}$, et al. Reprogramming of intestinal glucose metabolism and glycemic control in rats after gastric bypass. Science. (2013) 341:406-10. doi: 10.1126/science.1235103

114. Troy S, Soty M, Ribeiro L, Laval L, Migrenne S, Fioramonti X, et al. Intestinal gluconeogenesis is a key factor for early metabolic changes after gastric bypass but not after gastric lap-band in mice. Cell Metab. (2008) 8:201-11. doi: 10.1016/j.cmet.2008.08.008

115. Thorens B, Larsen PJ. Gut-derived signaling molecules and vagal afferents in the control of glucose and energy homeostasis. Curr Opin Clin Nutr Metab Care. (2004) 7:471-8. doi: 10.1097/01.mco.0000134368.91900.84

116. Pozzilli P, Guglielmi C, Caprio S, Buzzetti R. Obesity, autoimmunity, and double diabetes in youth. Diabetes Care. (2011) 34:S16670. doi: $10.2337 / \mathrm{dc} 11-\mathrm{s} 213$

117. Dirksen C, Jacobsen SH, Bojsen-Møller KN, Jørgensen NB, Naver LS, Hvolris LE, et al. Reduction in cardiovascular risk factors and insulin dose, but no beta-cell regeneration 1 year after Roux-en-Y gastric bypass in an obese patient with type 1 diabetes: a case report. Obes Res Clin Pract. (2013) 7:e269-74. doi: 10.1016/j.orcp.2012.01.002

118. Madsbad S, Faber OK, Binder C, McNair P, Christiansen C, Transbøl I. Prevalence of residual beta-cell function in insulin-dependent diabetics in relation to age at onset and duration of diabetes. Diabetes. (1978) 27:2624. doi: 10.2337/diab.27.1.S262

119. Levetan C. Distinctions between islet neogenesis and $\beta$-cell replication: Implications for reversal of type 1 and 2 diabetes. J Diabetes. (2010) 2:7684. doi: 10.1111/j.1753-0407.2010.00074.x

120. Seisser. J. Latent (slowly progressing) autoimmune diabetes in adults. Curr Diab Rep. (2008) 8:94-100. doi: 10.1007/s11892-008-0018-x

121. Brophy S, Yderstraede K, Mauricio D, Hunter S, Hawa M, Pozzilli P, et al. Time to insulin initiation cannot be used in defining latent autoimmune diabetes in adults. Diab Care. (2008) 31:439-41. doi: 10.2337/dc07-1308

122. Hironaka JY, Kitahama S, Sato H, Inoue M, Takahashi T, Tamori $Y$. Sleeve gastrectomy induced remission of slowly progressive type 1 diabetes in a morbidly obese Japanese patient. Intern Med. (2019) 58:6758. doi: 10.2169/internalmedicine.1217-18

123. Uno K, Seki Y, Kasama K, Wakamatsu K, Hashimoto K, Umezawa A, et al. Mid-term results of bariatric surgery in morbidly obese Japanese patients with slow progressive autoimmune diabetes. Asian J Endosc Surg. (2018) 11:238-43. doi: 10.1111/ases.12443

124. Lindqvist A, Spegel P, Ekelund M, Garcia Vaz E, Pierzynowski S, Gomesz MF, et al. Gastric bypass improves beta-cell function and increases $\beta$-cell mass in a porcine model. Diabetes. (2014) 63:1665-71. doi: 10.2337/db13-0969

Conflict of Interest: The authors declare that the research was conducted in the absence of any commercial or financial relationships that could be construed as a potential conflict of interest.

Copyright (C) 2020 Korakas, Kountouri, Raptis, Kokkinos and Lambadiari. This is an open-access article distributed under the terms of the Creative Commons Attribution License (CC BY). The use, distribution or reproduction in other forums is permitted, provided the original author(s) and the copyright owner(s) are credited and that the original publication in this journal is cited, in accordance with accepted academic practice. No use, distribution or reproduction is permitted which does not comply with these terms. 


\section{GLOSSARY}

AGB: adjustable gastric banding

AgRP: agouti-related peptide

BAT: brown adipose tissue

BMI: body mass index

BPD: biliopancreatic diversion

DBP: diastolic blood pressure

CART: cocaine- and amphetamine-regulated transcript

DD: double diabetes

DKA: diabetic ketoacidosis

FGF19: fibroblast growth factor 19

fMRI: functional magnetic resonance imaging

GAD65: glutamic acid decarboxylase

Glc6Pase: glucose-6-phosphatase

GLP-1: glucagon-like peptide-1

GLP-1R: glucagon-like peptide-1 receptor

GLUT2: glucose transporter 2

HbA1c: glycosylated hemoglobin Alc

HDL: high-density lipoprotein

IGT: impaired glucose tolerance

IUs: international units

LADA: latent autoimmune diabetes of the adult

LDL: low-density lipoprotein

NPY: Neuropeptide Y

NTS: nucleus of the solitary tract

OGTT: oral glucose tolerance test

PCOS: polycystic ovarian syndrome

PEPCK: phosphoenolpyruvate carboxykinase

POMC: pro-opiomelanocortin

PYY: peptide YY

RYGB: Roux-en-Y gastric bypass

SBP: systolic blood pressure

SGLT1: glucose cotransporter 1

T1DM: type 1 diabetes mellitus

T2DM: type 2 diabetes mellitus

TGs: triglycerides

TWL: total weight loss

VLCD: very low-calorie diet

VSG: vertical sleeve gastrectomy 